\title{
Fibromyalgia syndrome and gestation. Case report*
}

\author{
Síndrome fibromiálgica e gestação. Relato de caso \\ Telma Regina Mariotto Zakka, Lin Tchia Yeng ${ }^{2}$, Manoel Jacobsen Teixeira ${ }^{1}$ \\ ${ }^{*}$ Received from Clinicas Hospital, School of Medicine, University of São Paulo, São Paulo, SP, Brazil.
}

\section{ABSTRACT}

BACKGROUND AND OBJECTIVES: The impact of fibromyalgia during gestation is not clearly defined. Its treatment is a challenge for the health team and drug prescription requires care and attention. This study aimed at evaluating treatment possibilities for a patient with chronic pain during gestation.

CASE REPORT: Patient with 32 years of age, with fibromyalgia and irritable bowel syndrome, with eight weeks gestation. Patient was being treated for one year in the Ambulatory of Chronic Abdominal, Pelvic and Perineal Pain, from the Interdisciplinary Pain Center of the Hospital.

CONCLUSION: Multidisciplinary treatment has involved drug replacement, physiotherapy, acupuncture, psychotherapy, postural and dietary reeducation.

Keywords: Drugs, Fibromyalgia, Gestation, Multidisciplinary treatment.

\section{RESUMO}

JUSTIFICATIVA E OBJETIVOS: O impacto da fibromialgia no decurso da gestação não é claramente definido. Seu tratamento constitui um desafio para a equipe de saúde e a prescrição farmacológica exige cuidado e atenção. O objetivo deste estudo foi analisar as possibilidades de tratamento de uma paciente com quadro de dor crônica durante a gestação. RELATO DO CASO: Paciente de 32 anos, com quadro de fibromialgia e síndrome do intestino irritável com gestação de oito semanas. Esta paciente encontrava-se, há um ano, em tratamento no Ambulatório de Dor Abdominal, Pélvica e Per-

1. University of São Paulo, School of Medicine, Clinicas Hospital, Interdisciplinary Pain Center, São Paulo, SP, Brazil.

2. University of São Paulo, School of Medicine, Clinicas Hospital, Institute of Orthopedics and Traumatology, São Paulo, SP, Brazil.

Submitted in January 03, 2014.

Accepted for publication in May 19, 2014.

Conflict of interests: none.

\section{Correspondence to:}

Telma Regina Mariotto Zakka

R. Antonio Valente da Silva, 141

12080-230 São Paulo, SP, Brasil.

E-mail: trmzakka@gmail.com

(c) Sociedade Brasileira para o Estudo da Dor ineal Crônica do Centro Interdisciplinar de Dor do Hospital. CONCLUSÁO: $O$ tratamento multidisciplinar abrangeu a modificação dos fármacos, fisioterapia, acupuntura, psicoterapia, reeducação postural e alimentar.

Descritores: Fármacos, Fibromialgia, Gestação, Tratamento multidisciplinar.

\section{INTRODUCTION}

Anatomic and functional changes during gestation may trigger, worsen or change pain expression, especially musculoskeletal pain. Women with chronic pain, such as fibromyalgia syndrome and irritable bowel syndrome may have symptoms associated to discomforts inherent to this period.

The choice of therapeutic interventions is a dilemma requiring adequate planning to offer analgesia with the least possible risk for mother and fetus ${ }^{1,2}$. When establishing the pharmacological treatment, it is important to consider gestational age, placenta and fetus, with their own characteristics.

Approximately 1 to $2 \%$ of congenital malformations are caused by drugs, and 4 to $5 \%$ by other chemical agents. Teratogenic agents produce changes in embryonic and/or fetal morphology and physiology and teratogenesis is considered not only anatomic-functional deformities, but also functional and behavioral changes, growth delay and neuromotor development delay ${ }^{1-4}$.

Drugs used during gestation may alter placental blood flow and induce fetal injuries by decreasing oxygen and nutrients supply, and may be present in fetal circulation at birth.

During lactation, several drugs are excreted in maternal milk and are a potential source of toxicity for the infant. The binding of drugs to maternal milk plasma proteins is related to the fraction which remains in maternal circulation and to the free fraction transferred to the milk. Substances with a high protein binding rate are excreted in small amounts in the milk and decrease infants' exposure, and drugs with low lipossolubility and those hydrosoluble are slowly transmitted to maternal milk and should be the choice for breastfeeding women ${ }^{1-4}$. This study aimed at evaluating treatment possibilities for a patient with chronic pain during gestation.

\section{CASE REPORT}

Patient with 32 years of age, executive secretary, with diffuse pain throughout the body, non-repairing, light and restless sleep, moderate depression, anxious, sensation of edema in 
lower limbs, low back pain, fatigue, difficulty to concentrate and migraine episodes for three years. For one year she has abdominal pain or discomfort, at least three days a week, sensation of abdominal distension, obstipation and hard stools. Laboratory and imaging exams are normal.

After exhaustive investigation, patient was diagnosed with fibromyalgia and irritable bowel syndrome and pharmacological treatment was started with duloxetine $(90 \mathrm{mg})$, afterward associated to pregabalin $(300 \mathrm{mg})$, in addition to mebeverine hydrochloride (400mg) and dipirone (2000mg) day. As complementation of the therapeutic plan, she was being followed up with physiotherapy (kinesiotherapy) and psychotherapy. She returned with eight weeks gestation, referring severe pain, visual analog pain scale $=9$ (VAS), poor sleep with several awakenings and very anxious. She informed that had abruptly interrupted medications and physiotherapy, one month ago, when she learned that she was pregnant.

Patient was informed of the need for multidisciplinary follow up with the use of drugs, acupuncture, dietary and postural re-education and psychotherapy. Duloxetine and pregabalin where withdrawn and maprotiline was prescribed $(25 \mathrm{mg})$ subsequently increasing the dose to $75 \mathrm{mg}$, associated to dipirone $(2000$ to $3000 \mathrm{mg} /$ day). Symptoms were adequately controlled during gestation.

\section{DISCUSSION}

Care of painful pregnant women and infants should contemplate the etiologic treatment, the identification and modification of factors contributing to its expression, including psychic and operational functions of different systems and apparatus contributing to distress. Adaptation of analgesic schedules, orientations about pain mechanisms and reasons and risks of procedures proposed to its control decrease the underutilization of drugs and the undertreatment of symptoms, improving treatment adherence and final result.

When choosing a drug, it is important to know its safety profile in different gestation and lactation stages, the level of protein binding, lipid solubility, molecular weight and maternal metabolic characteristics which influence maternal-fetal transfer of substances ${ }^{1,2,4}$. Except for large polar molecules, most drugs cross the placenta and reach the fetus ${ }^{5,6}$.

To guide drugs prescription during gestation and lactation, the Food and Drug Administration (FDA) in the United States of America (USA) has developed a risk classification based on drug potential to cause fetal malformations ${ }^{2,4-9}\left(\mathrm{Ta}^{-}\right.$ ble 1).

In our case, we decided to withdraw category $\mathrm{C}$ drugs for fetal safety. Maprotiline is safer than previously used drugs. Dipirone and paracetamol may be used by pregnant patients to control both acute and chronic pain. In addition, pregnant patients should always be encouraged to use well oriented non-pharmacological therapies.

\section{CONCLUSION}

Treating acute and chronic pain during gestation and lactation is a challenge for physicians and a major concern to women and, very often, determines undertreatment and drugs underutilization, causing unnecessary distress and unfavorable clinical evolution. When prescribing a drug during gestation or lactation, one should consider the binomial mother-fetus and critically and individually analyze choices and decisions.

Table 1. Food and Drug Administration (USA) risk classification for drugs used during pregnancy to control pain $2,4,7$

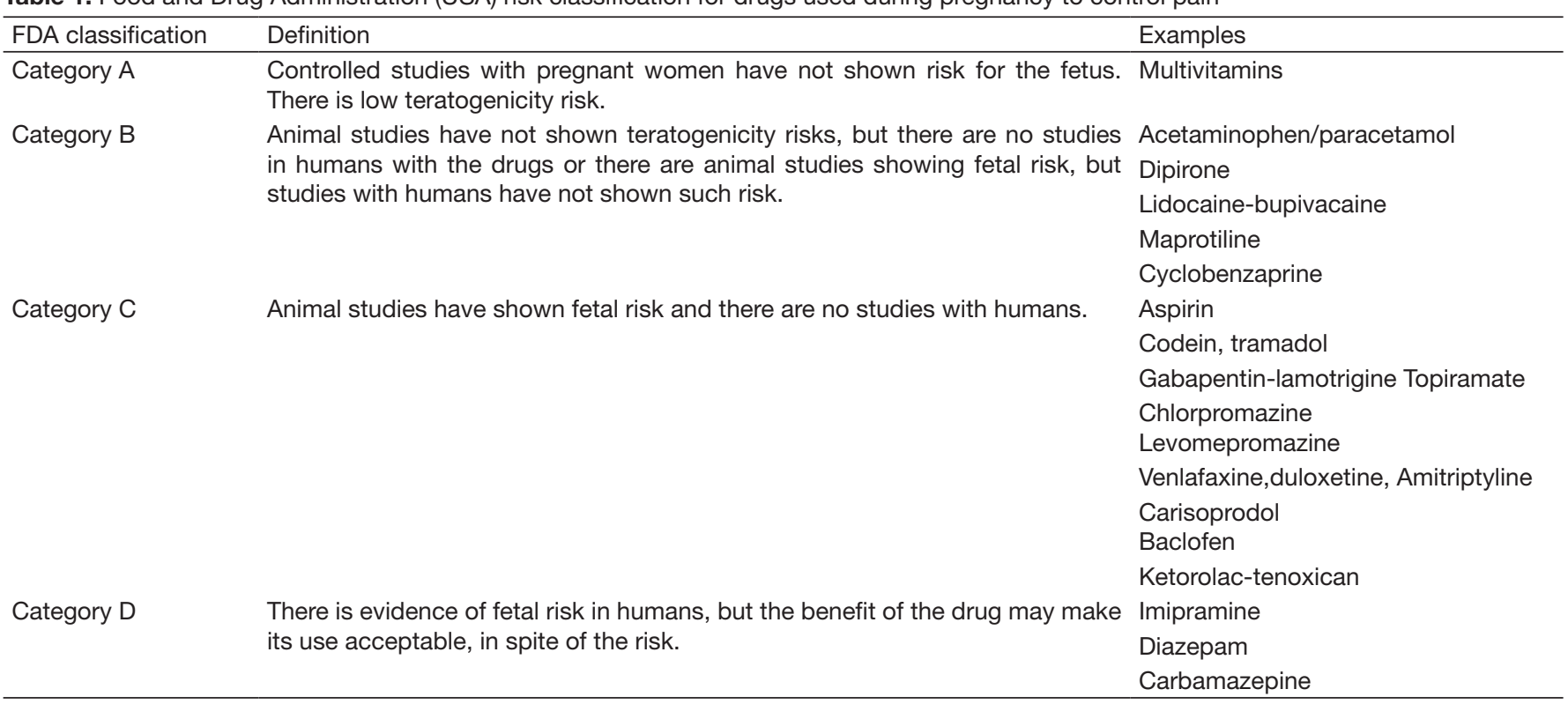




\section{REFERENCES}

1. American Academy of Pediatrics Committee on Drugs. Use of psychoactive medication during pregnancy and possible effects on the fetus and newborn. Pediatrics. 2000;105(4):880-7.

2. American Society of Health-System Pharmacists. Pharmacist's Drug Handbook, Bethesda, MD; 2002. 1282p.

3. Federação Brasileira das Sociedades de Ginecologia e Obstetrícia. Manual de Orientação. Drogas na Gravidez. Sáo Paulo: Ponto Editora; 2003. 178p.

4. Blake DA, Niebyl JR. Requirements and limitations in reproductive and teratogenic risk assessment. In: Niebyl JR, (editor). Drug use in pregnancy. Philadelphia: Lea and Febiger; 1988. 1-9p.
5. Kulay LJ, Kulay MNC, Lapa AJ. Drogas na gravidez e na lactação: Guia Prático. São Paulo: Manole Editora; 2007. 697p.

6. BaldessarinI RJ. Tratamento farmacológico da depressão e dos transtornos de ansiedade. In: Goodman e Gilman: As Bases Farmacológicas da Terapêutica. 11 ed. Rio de Janeiro: McGraw-Hill Interamericana do Brasil; 2006. 383-410p.

7. Chaney DS, Mihic, J, Harris RA. Hipnóticos e Sedativos. In: Goodman e Gilman: As Bases Farmacológicas da Terapêutica. 11 ed. Rio de Janeiro: McGraw-Hill Interamericana do Brasil; 2006. 359-79p.

8. EUA. Departamet of Health and Humans Service. U.S. Food and Drug Administration (FDA) - center for Drug Evaluation and Research. Disponível em URL:http:// www.fda.gov/cder/index.html.

9. Marks JM, Spatz DL. Medications and Lactation: What PNPs need to Know. J Pediatr Health Care. 2003;17(6):311-7 